\title{
The genus Ramalina (Ascomycota, Lecanoromycetes, Ramalinaceae) from the Scattered Islands (French Southern and Antarctic Lands), with descriptions of three new species
}

\author{
Rémy Poncet ${ }^{1 *}$, Françoise Lohézic - Le Dévéhat ${ }^{2 *}$, Solenn Ferron ${ }^{2}$, Jean Hivert ${ }^{3}$, \\ Christian Fontaine ${ }^{3}$, Frédéric Picot ${ }^{3}$, Ehoarn Bidault ${ }^{4,5}$ \& Lionel Kervran ${ }^{6}$
}

\section{Article info}

Received: 30 Jun. 2021

Revision received: 27 Nov. 2021

Accepted: 1 Dec. 2021

Published: 31 Dec. 2021

\section{Associate Editor}

Martin Kukwa

\begin{abstract}
A systematic survey of lichens was performed in 2019 in four of the five territories constituting the French Scattered Islands (Europa Island, Juan de Nova, Glorioso Islands, and Tromelin) focusing on the genus Ramalina. Species were characterized using morphological (macroscopic and microscopic) features and an accurate chemical profiling method based on high-performance liquid chromatography coupled with diode-array detection and electrospray ionization tandem mass spectrometry (HPLC-DAD-MS). Five species were found in these territories. Two of them, Ramalina dumeticola and $R$. ovalis, are already known. Three species are introduced here as new to science: Ramalina gloriosensis sp. nov., $R$. hivertiana sp. nov., and $R$. marteaui sp. nov. An identification key is provided for the species found in the area and morphologically closely related taxa.
\end{abstract}

Key words: Mozambique Channel, Ramalinaceae, Corticolous, Europa Island, Juan de Nova, Glorioso Islands

\section{Introduction}

The lichen genus Ramalina exhibits a cosmopolitan distribution and hosts an important taxonomic diversity. With about 240 species currently recognized, it is the eighteenth most diverse lichen genera and is thus considered as 'hyperdiverse' (Lücking et al. 2017). This genus includes a large number of species with restricted geographical ranges of extension, that are endemic to islands, or to ecologically particular territories (Krog \& Østhagen 1980; Stevens 1987; Krog 1990; Blanchon et al. 1996; Aptroot \& Bungartz 2007; Aptroot 2008; Aptroot \& Schumm 2008; Pérez-Vargas \& Pérez-Ortega

\footnotetext{
${ }^{1}$ UMS 2006 PatriNat (OFB - CNRS - MNHN), Muséum national d'Histoire naturelle, Maison Buffon, CP41, 36 rue Geoffroy Saint-Hilaire 75005 Paris, France. ORCID: 0000-0003-1070-3685

${ }^{2}$ Univ Rennes, CNRS, ISCR (Institut des Sciences Chimiques de Rennes) - UMR 6226, 35000 Rennes, France

${ }^{3}$ Conservatoire botanique national de Mascarin, 2 rue du Père Georges 97436 Saint-Leu, La Réunion, France

${ }^{4}$ Missouri Botanical Garden, Africa \& Madagascar Department, 4344 Shaw Blvd., St. Louis, MO 63110, USA

${ }^{5}$ Institut de Systématique, Évolution et Biodiversité, ISYEB - Muséum national d'Histoire naturelle, Centre national de la Recherche scientifique, Sorbonne Université, École pratique des Hautes Études, Université des Antilles, case postale 39, 57 rue Cuvier, F-75231 Paris cedex 05, France

${ }^{6}$ Direction des collections, Muséum national d'Histoire naturelle, CP 39 , 57 rue Cuvier, 75231 Cedex 05 Paris, France

* Corresponding authors e-mail: remy.poncet@mnhn.fr, francoise.le-devehat@univ-rennes1.fr
}

2014; Sparrius et al. 2017). Regarding the African realm, the genus has been extensively studied (Dodge 1971; Krog \& Swinscow 1974, 1975, 1976; Swinscow \& Krog 1988; Krog 1994; Bock et al. 2007; Fryday 2014), notably in East Africa, where a large number of the Ramalina species recorded are restricted to the African continent (Krog \& Swinscow 1976). However, when considering islands of the Western Indian Ocean, available data concerning Ramalina become scarcer, though some territories have recently been targeted by field work or subjected to literature surveys: Seychelles (Seaward \& Aptroot 2009; Neuwirth \& Stocker-Wörgötter 2017), Mauritius (Diederich \& Ertz 2020), and Madagascar (Aptroot 2016). Taken together, these last references list eleven accepted Ramalina species for the region, which is notably lower than the fifteen species recorded from the Galapagos only (Aptroot \& Bungartz 2007), or the fifty-four species recorded from the Atlantic Islands (Aptroot \& Schumm 2008). This paper aims at contributing to the knowledge of the genus Ramalina in the Mozambique Channel and Western Indian Ocean, in particular the Scattered Islands (French Southern and Antarctic Lands): Europa Island, Juan de Nova, Glorioso Islands, and Tromelin (Fig. 1) where extensive field surveys were performed in 2019 . 


\section{Material and methods}

\section{Surveyed territories and sampling methodology}

Europa Island, Juan de Nova, Glorioso Islands, and Tromelin constitute, along with Bassas da India (an atoll of only $0.2 \mathrm{~km}^{2}$, which is merely totally submerged at high tide), the fifth district of the French Southern and Antarctic Lands (TAAF). The emerged surface of these territories is less than $40.4 \mathrm{~km}^{2}$ altogether (Boullet et al. 2018), and the elevation is very low, as the highest recorded point is $14 \mathrm{~m}$ a.s.l. at Glorioso Islands. The Scattered Islands constitute oceanic sanctuaries of primitive nature and host a remarkable land and marine biological heritage, which has been mostly preserved due to the geographical isolation, and a historically very limited human occupation. Today, these territories are uninhabited, except for the military and scientists, and most of them benefit from protection status: Europa Island, Bassas da India and Tromelin are protected by a prefectural decree which classifies them as a nature reserve since 1975, and the Glorioso Islands are classified as a national nature reserve since 10 June 2021. Juan de Nova benefits from no regulatory conservation status. Regarding climate, according to Beck et al. (2018) Köppen-Geiger climate classification, Europa Island climate is 'BSh' (main climate: arid, precipitation: steppe, temperature: hot arid), and Juan de Nova, Glorioso Island, and Tromelin are 'Aw' (main climate: tropical savannah, precipitation: dry winter). Ramalina species were surveyed in 2019 within the framework of the RECOFFIE Project ('Renforcement des Connaissances sur la Flore et la Fonge des Iles Eparses'), in four of the five territories constituting the Scattered Islands (Fig. 1). During 3 to 4 days for each of the four surveyed territories, all observed species of Ramalina were collected. Samples were stored dry in paper envelopes, and associated with collection number, ecological information (phorophytes, when applicable, were identified), date, and location obtained from a field GPS device. Species were surveyed on all potential ecological substrates: bark, wood, rock, and soil.

\section{Morphological and anatomical studies}

Morphological and anatomical studies were performed using a Zeiss Stemi SV8 stereomicroscope and a Leitz Orthoplan compound microscope with phase contrast, connected to a Sony E3CMOS camera sensor. Handmade sections were mounted in tap water, from which all measurements were taken. Ascospore measurements indicate the minimum and maximum values ( $n$ indicates the number of ascospores measured), and the value in parentheses indicates an exceptionally lower or higher value, which was only observed once among the measured ascospores. In all other criteria, values in parentheses indicate extreme measurements. Anatomical structure of the lacinae is based on Krog \& Østhagen (1980) and Kashiwadani \& Kalb (1993). Chemical spot reactions have been tested on cortex, medulla, soralia, and apothecia

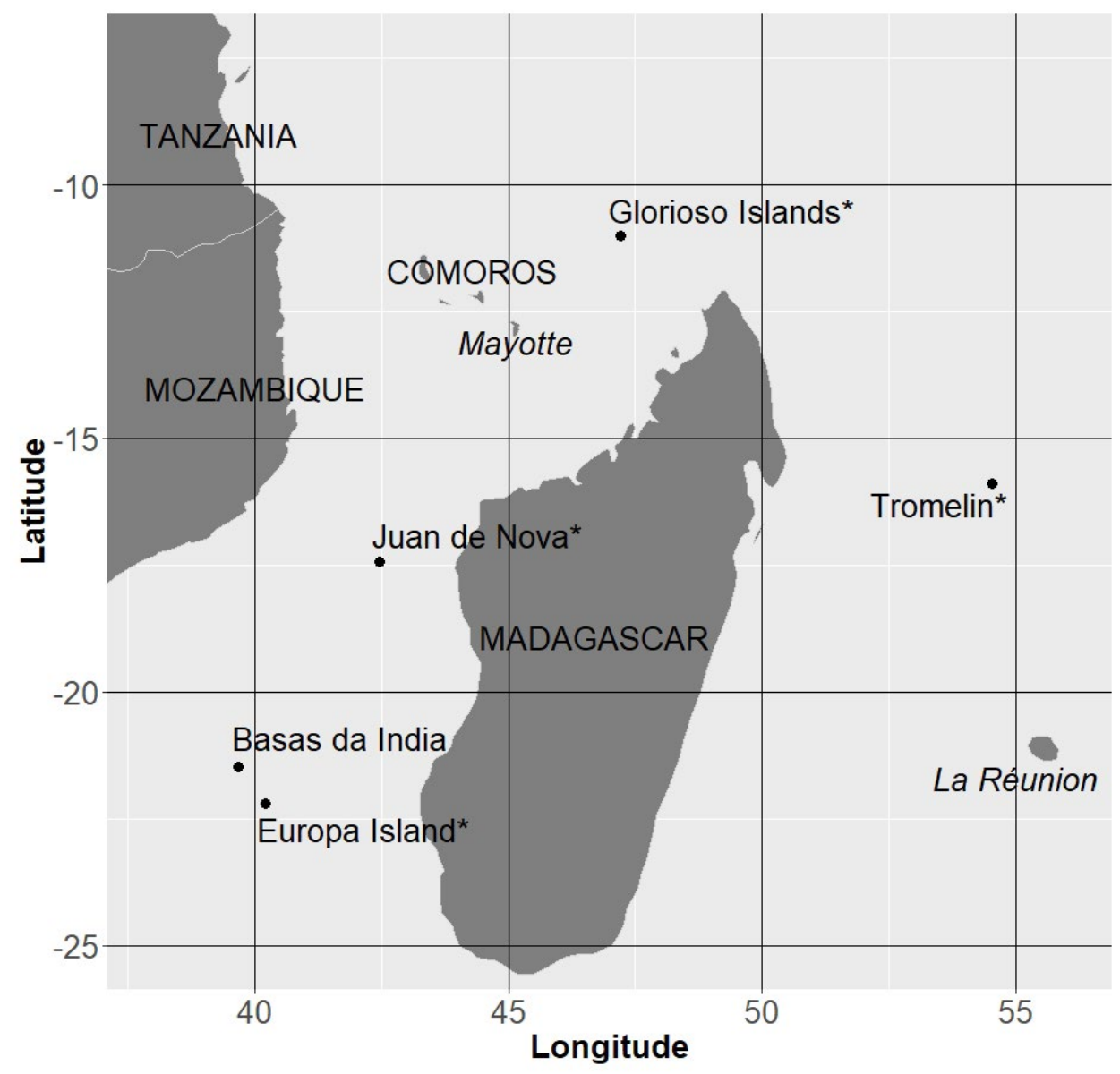

Figure 1. Map of surveyed locations. Territories in lower case not in italic correspond to the Scattered Islands. Only those marked with * have been surveyed. Territories in lower case in italic correspond to other French overseas territories. Countries are marked in upper case. 
excipulum and discus, they are abbreviated as $\mathrm{K}(10 \%$ $\mathrm{KOH}), \mathrm{C}$ (commercial bleach), KC (K followed by $\mathrm{C}$ ) and Pd (paraphenylenediamine), while UV refers to fluorescence at $366 \mathrm{~nm}$. A sign '-' indicates lack of reaction, and ' + ' indicates reaction followed by information on the reaction.

\section{Specimens chemical profiling}

About twenty milligrams $(8-30 \mathrm{mg}$ ) of each lichen sample were ground and extracted with acetone $(1 \mathrm{~mL})$ using an ultrasound bath at $30-40^{\circ} \mathrm{C}$ for 45 minutes. These extractions were repeated three times and all three extracts were mixed. After evaporation of the solvents, all dried extracts were weighed to prepare a solution at a concentration of $1 \mathrm{mg} \cdot \mathrm{mL}^{-1}$ in methanol. All extracts were filtered $(0.45 \mu \mathrm{m})$ before being subjected to high-performance liquid chromatography coupled with diode-array detection and electrospray ionization tandem mass spectrometry (HPLC-DAD-MS) with the method previously reported (Ferron et al. 2020). In addition, three custom chemical databases were used: the HLDB built with authentic lichen standards, the RamalinaDB built from an extensive bibliography on compounds identified in Ramalina species coupled with their predicted retention time and their molecular weight, and the LDB-MS1, a database built by Damien Olivier-Jimenez (Ferron et al. 2020). All databases allowed a dereplication of the molecules suspected to be in the extracts. However, some detected ions exhibited an $\mathrm{m} / \mathrm{z}$ which may correspond to several lichen compounds of same molecular formula. The dereplication was thus refined by the complete spectrum analysis which allowed taking into account in-source fragments.

Mass spectrometry and UV allow the detection of metabolites that wouldn't be revealed by TLC, and gap filling step in MZmine revealed the presence at trace level of almost all detected compounds in each sample.
Atranorin is known (Le Pogam 2017) to be hardly detected under our ionization conditions, but is well identified by HPLC/DAD and was found to be present in most of the samples. Moreover, some of the trace compound detected both by UV and mass spectrometry are still unidentified.

\section{Results and discussion}

During our studies we have recorded five putative species from the Scattered Islands. Three of them represent new species to science. All species found in this study are described below.

The survey of Ramalina species from the Scattered Islands allowed the recording five species, among which three are new to science. All species are corticolous and were found growing on widespread phorophytes. Suriana maritima, a pantropical coastal shrub, constitutes a suitable host, as all five Ramalina species were recorded growing on it. The other phorophytes were Delonix regia (with $R$. ovalis), Casuarina equisetifolia (with $R$. gloriosensis), Heliotropium foertherianum (with $R$. gloriosensis), and Guettarda speciosa (with $R$. gloriosensis). Among the recorded Ramalina species, $R$. gloriosensis was growing on four different phorophytes, $R$. ovalis on two, and the other three species only on $S$. maritima. Despite our intensive fieldwork efforts, no Ramalina was recorded from Tromelin (Table 1), which can be considered as the most remote island among the surveyed territories, notably because it is located outside the Mozambique Channel to the East of Madagascar (Fig. 1). The absence of Ramalina species there could partly be explained by the absence of the most suitable phorophyte species, $S$. maritima (Boullet et al. 2018). However, H. foertherianum constitutes rather vast shrublands in this territory, which was shown from the Glorioso Islands to be a suitable phorophyte for Ramalina species. Another notable result is that, despite

Table 1. Ramalina species reported from the Scattered Islands and results of chemical profiling $(\mathrm{MS}=$ mass spectrometry; UV = ultraviolet; $\mathbf{M}=$ major compound; $\mathbf{m}=$ minor compound; $\mathrm{t}=$ trace compound).

\begin{tabular}{|c|c|c|c|c|c|c|c|c|}
\hline \multicolumn{4}{|l|}{ Territories surveyed } & $\begin{array}{c}\text { Ramalina } \\
\text { dumeticola }\end{array}$ & \begin{tabular}{|c|} 
Ramalina \\
gloriosensis
\end{tabular} & $\begin{array}{l}\text { Ramalina } \\
\text { hivertiana }\end{array}$ & $\begin{array}{l}\text { Ramalina } \\
\text { marteaui }\end{array}$ & $\begin{array}{c}\text { Ramalina } \\
\text { ovalis }\end{array}$ \\
\hline \multirow{4}{*}{\multicolumn{4}{|c|}{$\begin{array}{r}\text { Europa } \\
\text { Juan de Nova } \\
\text { Glorioso Islands } \\
\text { Tromelin } \\
\end{array}$}} & - & - & $\mathrm{X}$ & - & $\mathrm{X}$ \\
\hline & & & & $\mathrm{X}$ & - & - & - & - \\
\hline & & & & - & $\mathrm{X}$ & - & $\mathrm{X}$ & - \\
\hline & & & & - & - & - & - & - \\
\hline \multicolumn{4}{|l|}{ Chemical compounds } & & & & & \\
\hline Identity & $\begin{array}{l}\mathrm{RT} \\
(\mathrm{min})\end{array}$ & $\mathrm{m} / \mathrm{z}$ & $\begin{array}{l}\text { ([M-H]-, } \\
\text { in-source } \\
\text { fragments) }\end{array}$ & & & & & \\
\hline 4'-O-methylnorsekikaic acid & 24.5 & 403 & $225 ; 195$ & $\mathrm{t}$ & $\mathbf{m}$ & $\mathbf{m}$ & $\mathrm{t}$ & - \\
\hline 4'-O-demethylsekikaic acid | subpaludosic acid* & 24.8 & 403 & $211 ; 209$ & $\mathrm{t}$ & $\mathbf{m}$ & $\mathbf{m}$ & $\mathrm{t}$ & - \\
\hline cryptochlorophaeic acid & 26.1 & 459 & $239 ; 211$ & $\mathrm{t}$ & $\mathrm{t}$ & $\mathrm{t}$ & $\mathbf{M}$ & - \\
\hline 4'-O-methylnorhomosekikaic acid & 27.4 & 431 & $253 ; 195$ & $\mathbf{m}$ & $\mathrm{t}$ & $\mathrm{t}$ & $\mathrm{t}$ & $\mathrm{t}$ \\
\hline 2-O-methylnordivaricatic acid | divaricatic acid* & 28.4 & 387 & $195 ; 177$ & $\mathrm{t}$ & $\mathrm{t}$ & $\mathrm{t}$ & $\mathrm{t}$ & - \\
\hline 2,4'-di-O-methylnorsekikaic acid | sekikaic acid* & 28.9 & 417 & $225 ; 209$ & $\mathbf{M}$ & $\mathbf{M}$ & M & $\mathrm{t}$ & - \\
\hline usnic acid & 29.8 & 343 & & $\mathbf{m}$ & m & $\mathbf{m}$ & m & $\mathbf{M}$ \\
\hline atranorin & 30.3 & & & $\mathbf{m}$ & $\mathrm{t}$ & $\mathrm{t}$ & $\mathrm{t}$ & $\mathrm{t}$ \\
\hline $\begin{array}{l}\text { 4'-O-methylpaludosic acid | homosekikaic acid | } \\
\text { ramalinic acid }\end{array}$ & 31.6 & 445 & $253 ; 209$ & $\mathbf{M}$ & $\mathbf{m}$ & $\mathbf{m}$ & $\mathrm{t}$ & - \\
\hline
\end{tabular}

* pairs of compounds that can not be distinguished and only differ from the inversion of methoxy and hydroxy group at C2-C4 positions. 
the relative ecological and climatic similarities among the surveyed territories, none of the Ramalina species were recorded in several islands (Table 1). Two species were recorded from Europa Island, two others from the Glorioso Islands and only one from Juan de Nova. Compared with the only other lichen genus producing fruticose corticolous species recorded from the Scattered Islands: Roccella DC. (Ascomycota, Arthoniomycetes, Roccellaceae), this result contributes to shedding light on the dispersal abilities of the Ramalina species growing in these territories. Indeed, among Roccella species previously reported from the Scattered Islands, two species with sexual dispersal were only reported from Europa Island: Roccella applanata and Roccella belangeriana, while one species with asexual dispersal (soralia) was reported from three of the four surveyed territories: Roccella montagnei from Europa Island, Juan de Nova, and the Glorioso Islands (Ferron et al. 2020). So, when considering Roccella genus from the Scattered Islands, the species with asexual dispersal means seem to have better dispersal abilities, however, this cannot be generalized to the Ramalina species from these territories, for which sexual or asexual dispersal strategy seems to result both in rather low dispersal abilities. This hypothesis is supported by the fact that none of them were recorded from several territories from the Scattered Islands, and is in line with the high endemism rate observed within this genus. Indeed, Aptroot \& Bungartz (2007) and Aptroot \& Schumm (2008) reported many endemic Ramalina species from insular territories: the Azores (4 species), Canary Islands (11 species), Galapagos Islands (4 species), Madeira (7 species), and Saint Helena Island (5 species). It is still unclear if the three species described here are really endemic to their respective islands, but owing to the general trend inside the Ramalina genus and available data from the Western Indian Ocean and Eastern Africa, we can infer that these three new species may have rather restricted extension areas. Finally, combined with already available recent records from the Western Indian Ocean and the Mozambique Channel, including Madagascar, sixteen species are now reported from this area: Ramalina arabum (Dill. ex Ach.) Meyen \& Flot. (Madagascar, Mauritius), Ramalina celastri celastri (Spreng.) Krog \& Swinscow (Madagascar, Seychelles), Ramalina consanguinea Müll. Arg. (Madagascar), Ramalina dendriscoides Nyl. (Madagasacar, Seychelles) Ramalina dumeticola (Juan de Nova), Ramalina fecunda Krog \& Swinscow (Seychelles), Ramalina fimbriata Krog \& Swinscow (Madagascar), Ramalina gloriosensis (Glorioso Islands), Ramalina hivertiana (Europa Island), Ramalina leiodea (Nyl.) Nyl. (Mauritius), Ramalina litorea G. N. Stevens (Mauritius), Ramalina marteaui (Glorioso Islands), Ramalina nervulosa (Müll. Arg.) Abbayes (Mauritius, Seychelles), Ramalina ovalis (Europa Island), Ramalina praetermissa Abbayes (Madagascar), and Ramalina sprengelii Krog \& Swinscow (Mauritius, Seychelles).

\section{Taxonomic treatment}

Ramalina dumeticola Krog \& Swinscow

Description. Thallus corticolous, dull, greenish-yellowish to greyish-stramineous, fruticose, to $4-5 \mathrm{~cm}$ high, holdfast present, moderately branched, branching predominantly dichotomous with angle often less than $70-80^{\circ}$. Branches solid, flattened (generally up to the distal part, but sometimes subterete distally), 0.5-1.2 mm wide, with faint longitudinal laminal and marginal short elongate pseudocyphellae of $0.2-0.5 \mathrm{~mm}$ length, apices attenuate, forked or broken. Internal structure of the laciniae interrupted farinacea type, with distinguishable 10-15 $\mu \mathrm{m}$ thick cortex, and non-cracked chondroid tissue forming separated strands adjoining the broken cortex at pseudocyphellae locations. Soralia marginal, ellipsoid to elongate, $0.7-1.2$ $\times 0.2-0.4 \mathrm{~mm}$. Soredia rounded, 20-40 $\mu \mathrm{m}$ diam, farinose. Apothecia rare, marginal, lecanorine, $0.8-1.3 \mathrm{~mm}$ diam., thalline exciple without pseudocyphellae, sometimes slightly crenulate. Hymenium hyaline, 25-35 $\mu \mathrm{m}$ high, paraphyses simple, apically furcate, $1-1.5 \mu \mathrm{m}$ wide. Epithecium 10-12 $\mu \mathrm{m}$ high, brownish-olivaceous, with a layer of calcium oxalate crystals (1-4 $\mu \mathrm{m}$ diam.) visible in polarized light, dissolving in K. Hypothecium hyaline, $30-40 \mu \mathrm{m}$ high, with an algal layer below forming ovate clusters $(15-20 \times 20-30 \mu \mathrm{m})$ of rounded photobiont cells (4-7 $\mu \mathrm{m}$ diam.). Amphithecium of three layers, the external one consisting of 20-25 $\mu \mathrm{m}$ thick cortex, the second one of more or less abundant remains of chondroid tissue (up to 5-15 $\mu \mathrm{m}$ thick), and the last one of algal cells (4-7 $\mu \mathrm{m}$ diam.) intertwined with medulla and calcium oxalate crystals (2-10(12) $\mu \mathrm{m}$ diam.) visible in polarized light, partially dissolving in K. Asci subclavate-cylindrical, 20-25 × 5-8 $\mu \mathrm{m}(\mathrm{n}=5), 8$-spored. Ascospores hyaline (surface seeming micro-verrucose), 12-14(16) $\times$ 4-5 $\mu \mathrm{m}(\mathrm{n}=20), 1$-septate, narrowly ellipsoid to oblong with rounded ends, straight. Pycnidia not seen.

Chemistry. Major compounds: sekikaic acid or its positional isomer and a compound with a molecular peak $\mathrm{m} / \mathrm{z}=445$ which could be homosekikaic or 4'-O-methylpaludosic acids or ramalinic acid B. Minor compounds: 4'-O-methylnorhomosekikaic and usnic acids (Table 1). Spot tests: cortex P-, K-, KC-, C-, UV-; apothecial discs $\mathrm{P}-, \mathrm{K}+$ yellow turning pale wine (sometimes fleeting, best seen on young apothecia), $\mathrm{KC}+$ yellow-orange, $\mathrm{C}+$ yellow, UV-; medulla $\mathrm{P}-, \mathrm{K}+$ pink, $\mathrm{C}+$ pink, $\mathrm{KC}+$ pink, UV-.

Distribution and ecology. Coastal corticolous species occurring in Eastern Africa, Australia, and the Southeastern part of the Indo-Malay realm; growing on Suriana maritima.

Notes. The species belongs to the Ramalina farinacea complex. It is morphologically close to Ramalina farinacea, but it differs by the yellowish thallus tinge, the presence of minute linear pseudocyphellae, and the absence of protocetraric acid, salazinic acid, hypoprotocetraric acid, or norstictic acid (Yoshimura et al. 1994; Alvarez et al. 2001). It is also macroscopically close 


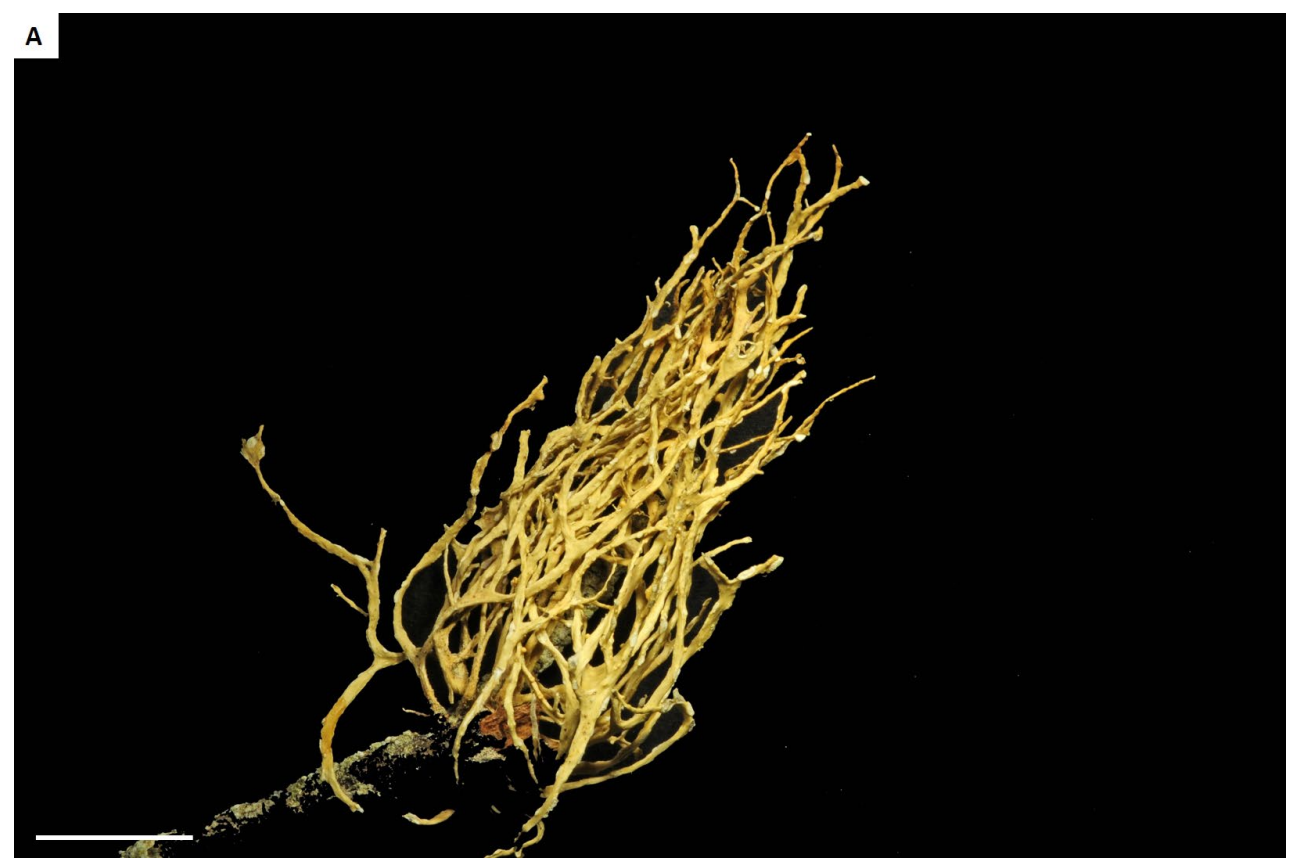

B
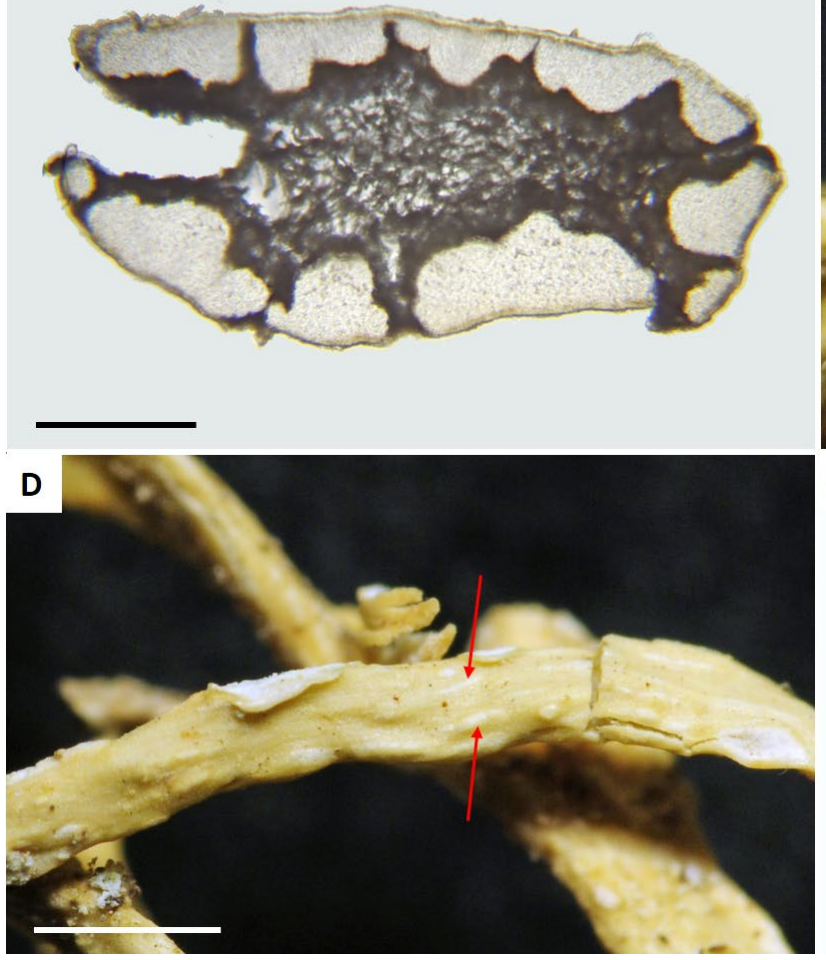

c

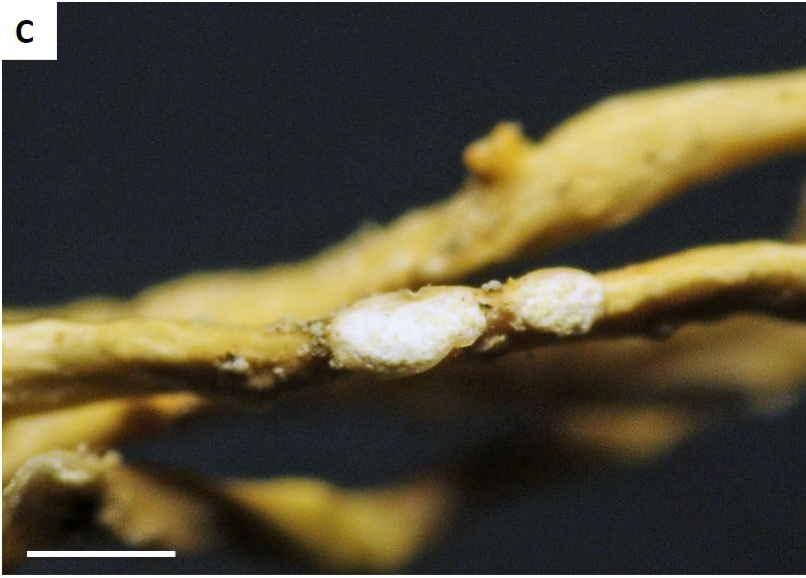

E

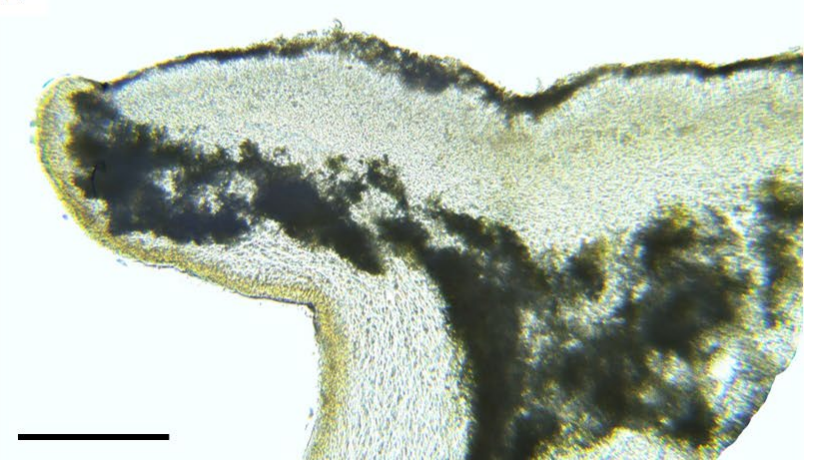

Figure 2. Ramalina dumeticola, PC0739884, collected in 2019 in Juan de Nova. A - habitus; B - internal structure of the laciniae; C - close-up of soralia; D - close-up of a branch showing texture, marginal soralia and pseudocyphellae (red arrows); E - apothecia cross-section in water. Scale $A=1 \mathrm{~cm} ; B=0.25 \mathrm{~mm} ; C=1 \mathrm{~mm} ; \mathrm{D}=2 \mathrm{~mm} ; \mathrm{E}=0.2 \mathrm{~mm}$.

to Ramalina nervulosa, but $R$. dumeticola has $\mathrm{K}+$ pink medulla and lacks divaricatic acid and stenosporic acid (Stevens 1983, 1987). Ramlina dumeticola is also similar to Ramalina luciae Molho, Bodo, W. L. Culb. \& C. F. Culb., but the latter differs by the branching pattern without extreme elongation between dichotomies, and the untwisted branches (Stevens 1983, 1987; Blanchon et al. 1996). Ramalina peruviana is also similar, but its soralia are punctiform often with fibrils, and the branching pattern is dense (Stevens 1987; Blanchon et al. 1996).
Ramalina pacifica Asahina is another similar species, but $R$. dumeticola differs by the yellowish thallus tinge, the non-splitting branches, the presence of marginal soralia, and the absence of salazinic acid (Stevens 1983, 1987; Blanchon et al. 1996; Oh et al. 2014).

Specimens examined. JUAN DE NOVA, $17^{\circ} 02^{\prime} 57.2400^{\prime \prime}$, $42^{\circ} 43^{\prime} 16.9874 " \mathrm{E}, 3 \mathrm{~m}$ a.s.1., corticolous on dead wood of Suriana maritima, 15 April 2019, leg. R. Poncet 151, C. Fontaine, J. Hivert, E. Bidault (PC0739884); JUAN DE NOVA, $17^{\circ} 02^{\prime} 57.1073^{\prime \prime} \mathrm{S}, 42^{\circ} 43^{\prime} 16.7523^{\prime \prime} \mathrm{E}, 3 \mathrm{~m}$ a.s.1., corticolous on 
Suriana maritima, 15 April 2019, leg. R. Poncet 153, C. Fontaine, J. Hivert, E. Bidault (PC0739883).

Ramalina gloriosensis R. Poncet sp. nov.

(Fig. 3)

MycoBank MB 841353

Diagnosis: Close to Ramalina dumeticola, but differing by the greyer thallus color, which has a waxy aspect, the wavier appearance, the quite clearly canaliculated branches on well-developed thalli (which have a more robust appearance), the wider branching angles (often close to $80-90^{\circ}$ ), the presence of 4'-O-methylnorsekikaic acid, and another metabolite that may belong to 4'-O-demethylsekikaic acid or subpaludosic acid, both as minor compounds.

Type: Glorioso Islands, $11^{\circ} 34^{\prime} 13.0101^{\prime \prime} \mathrm{S}, 47^{\circ} 17^{\prime} 43.6725^{\prime \prime} \mathrm{E}$, 5 m a.s.1., corticolous on Casuarina equisetifolia, 21 April 2019, leg. R. Poncet 155, F. Picot, J. Hivert, E. Bidault, (PC0739882 - holotype).

Description. Thallus corticolous, with a waxy aspect, greenish-grey, fruticose, to $5 \mathrm{~cm}$ high, but often shorter, holdfast present, moderately branched, branching predominantly dichotomous with wide-angle often close

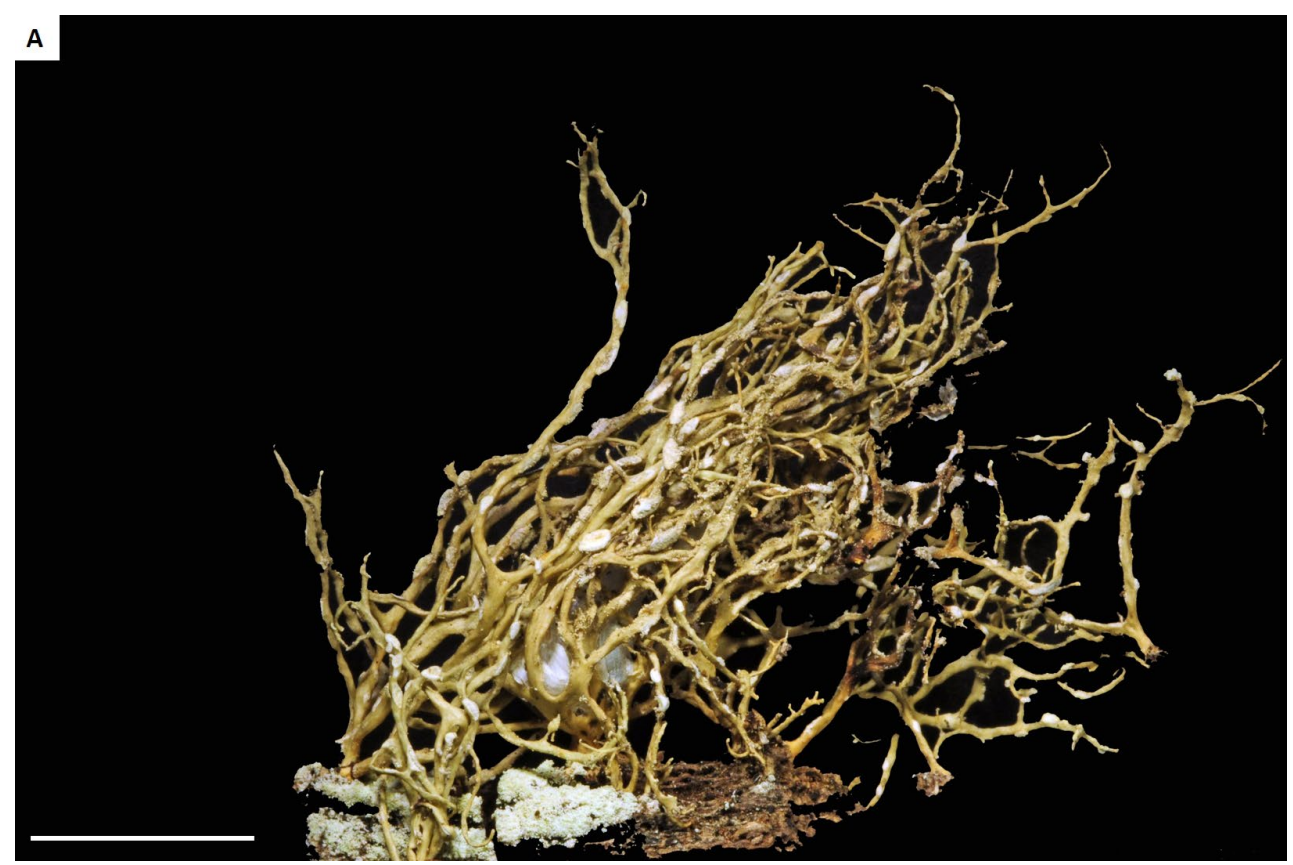

B
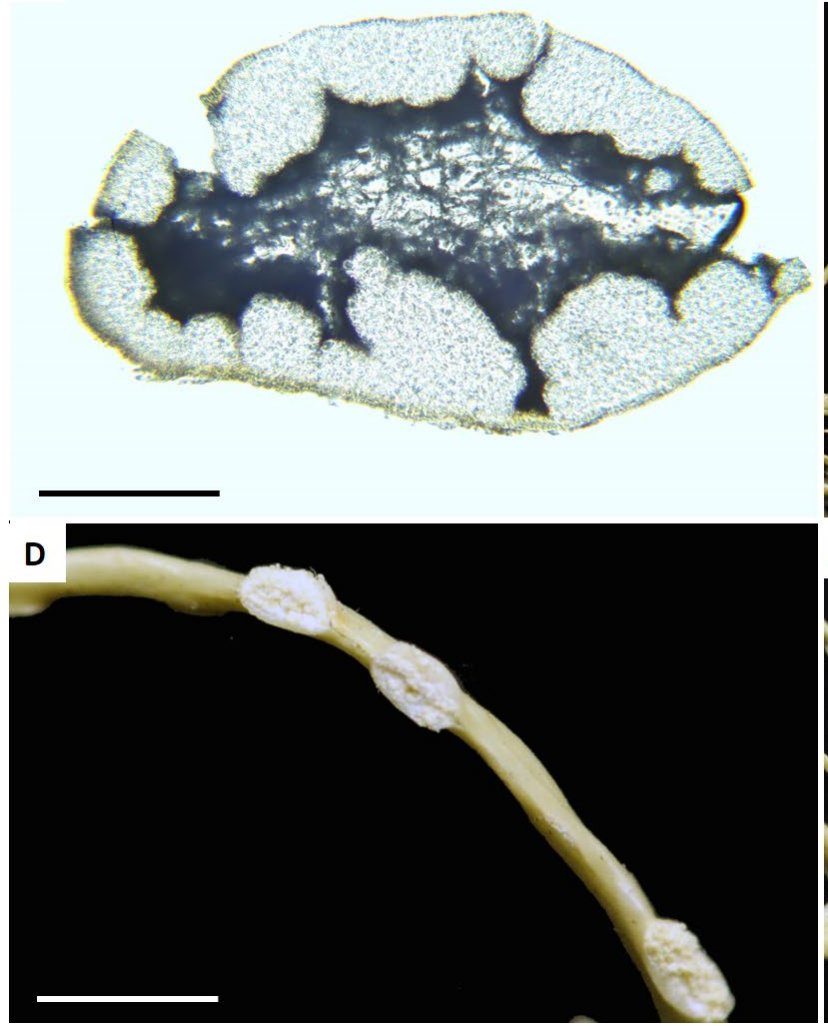

c

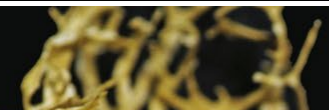

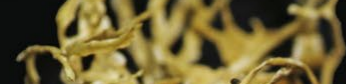
$\int_{-\infty}$

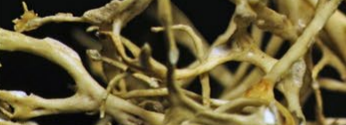

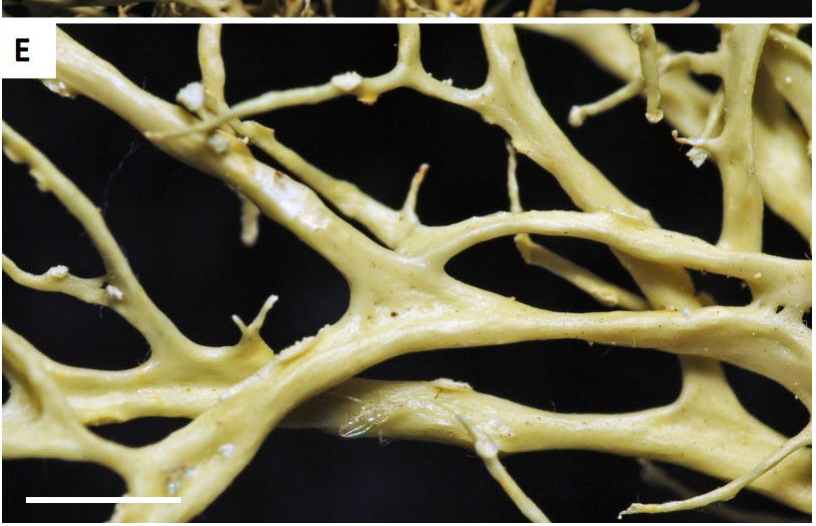

Figure 3. Ramalina gloriosensis, holotype. A - habitus; B - internal structure of the laciniae; C - close-up showing branching patterns; D - close-up showing soralia; E - close-up showing branches waxy texture. Scale A=1 cm; B=0.25 mm; C=5 mm; D-E=2 mm. 
to $80-90^{\circ}$. Branches solid, flattened to canaliculated on well-developed individuals, angular-terete in distal parts and young individuals, $0.5-1.2 \mathrm{~mm}$ wide, tapering apically, wavy to slightly convoluted, with marginal linear pseudocyphellae of $0.1-0.4 \mathrm{~mm}$ length (generally evolving to soralia) and faint rare longitudinal laminal striae (becoming more abundant in old branches). Internal structure of the laciniae interrupted farinacea type, with distinguishable $8-12 \mu \mathrm{m}$ thick cortex, and non-cracked chondroid tissue forming separated strands adjoining the unbroken cortex. Soralia marginal, ellipsoid, 0.6-1 $\times 0.15-0.3 \mathrm{~mm}$, sometimes becoming confluent and then irregularly elongate. Soredia rounded, 25-35 $\mu \mathrm{m}$ diam, farinose. Apothecia not seen. Pycnidia not seen.

Chemistry. Major compound: sekikaic acid (or its positional isomer). Minor compounds: 4'-O-methylnorsekikaic acid, usnic acid, and a compound which could be 4'-O-demethylsekikaic acid or subpaludosic acid (Table 1). Spot tests: cortex P-, K-, KC-, C-, UV-; medulla P-, K+ pinkish-winey (sometimes hard to see, best seen on well-developed individuals, and spot tests most visible after drying), $\mathrm{C}+$ pink (best seen on well-developed individuals), $\mathrm{KC}+$ pink (best seen on well-developed individuals), UV-.

Distribution and ecology. Coastal corticolous species only known from the Glorioso Islands, growing on Casuarina equisetifolia, Heliotropium foertherianum, Guettarda speciosa, and Suriana maritima.

Notes. The new species is morphologically very similar to Ramalina nervulosa, but differs by the absence of divaricatic acid and stenosporic acid, and the faint longitudinal pseudocyphellae (Stevens 1983, 1987). It also resembles Ramalina luciae, but differs in the branching pattern without extreme elongation between dichotomies, and the untwisted branches (Stevens 1983, 1987; Blanchon et al. 1996).

Etymology. The species is named after the Glorioso Islands where it was discovered. The spelling of the epithet is made up of glorios-, derived from 'Îles Glorieuses' in French, and the Latin suffix -ensis, place of origin.

Additional specimens. GLORIOSO ISLANDS, $11^{\circ} 34^{\prime} 17.2923^{\prime \prime}$, $47^{\circ} 17^{\prime} 53.4078^{\prime \prime}$ E, $3 \mathrm{~m}$ a.s.1., corticolous on Heliotropium foertherianum, 21 April 2019, leg. R. Poncet 156, F. Picot, J. Hivert, E. Bidault (PC0739887). GLORIOSO ISLANDS, $11^{\circ} 34^{\prime} 14.2821^{\prime \prime} \mathrm{S}$, $47^{\circ} 17^{\prime} 39.1627^{\prime \prime} \mathrm{E}, 3$ m a.s.l., corticolous on Guettarda speciosa, 21 April 2019, leg. R. Poncet 157, F. Picot, J. Hivert, E. Bidault (PC0739886). GLORIOSO ISLANDS, $11^{\circ} 34^{\prime} 13.0476^{\prime \prime} \mathrm{S}, 4^{\circ} 17^{\prime} 43.0459^{\prime \prime} \mathrm{E}, 3 \mathrm{~m}$ a.s.1., corticolous on Suriana maritima, 21 April 2019, leg. R. Poncet 158, F. Picot, J. Hivert, E. Bidault (PC0739885). GLORIOSO ISLANDS, $11^{\circ} 34^{\prime} 12.4942^{\prime \prime} \mathrm{S}, 4^{\circ} 17^{\prime} 30.7675^{\prime \prime} \mathrm{E}, 3 \mathrm{~m}$ a.s.l., corticolous on Suriana maritima, 20 April 2019, leg. R. Poncet 159, F. Picot, J. Hivert, E. Bidault Poncet (PC0739890); GLORIOSO ISLANDS, 11³4'17.3558"S, $47^{\circ} 17^{\prime} 53.6063^{\prime \prime} \mathrm{E}, 3 \mathrm{~m}$ a.s.1., corticolous on dead branches of Suriana maritima, 21 April 2019, leg. R. Poncet 165, F. Picot, J. Hivert, E. Bidault (PC0739892)

Ramalina hivertiana $\mathrm{R}$. Poncet, sp. nov.

(Fig. 4)

MycoBank MB 841354

Diagnosis: Close to Ramalina dumeticola, but differing by the darker stramineous to brownish ochraceous thallus color, the shorter, straighter and more rigid branches with conspicuous abundant longitudinal laminal striae, the narrower branching angles (often less than $70-80^{\circ}$ ), the absence of 4'-O-methylnorhomosekikaic as major or minor compound, the presence of a metabolite that may belong to 4'-O-demethylsekikaic acid or subpaludosic acid as minor compound, and a UV+ white medulla.

Type: Europa Island, $22^{\circ} 20^{\prime} 39.1581^{\prime \prime} \mathrm{S}, 40^{\circ} 20^{\prime} 21.7748^{\prime \prime} \mathrm{E}, 3 \mathrm{~m}$ a.s.1., corticolous on Suriana maritima, 11 April 2019, leg. R. Poncet 160, C. Fontaine, J. Hivert, E. Bidault (PC0739891 - holotype).

Description. Thallus corticolous, dull, dark stramineous to brownish ochraceous, fruticose, to $2(3) \mathrm{cm}$ high, but often shorter, holdfast present, sparsely branched, branching predominantly dichotomous with angle often less than $70-80^{\circ}$. Branches solid, flattened, becoming angular-terete in most distal parts, $0.3-1.1 \mathrm{~mm}$ wide, tapering apically, short, rather straight and brittle when dry, with marginal linear pseudocyphellae (generally evolving to soralia) and conspicuous abundant longitudinal laminal linear striae, both of $0.1-0.3 \mathrm{~mm}$ length. Internal structure of the laciniae interrupted farinacea type, with distinguishable 10-15 $\mu \mathrm{m}$ thick cortex, and non-cracked chondroid tissue forming separated strands adjoining the unbroken cortex (or broken cortex at pseudocyphellae locations). Soralia marginal, ellipsoid, $0.5-1 \times 0.2-0.3 \mathrm{~mm}$, or confluent and then irregularly elongate. Soredia rounded, 15-40 $\mu \mathrm{m}$ diam., farinose. Apothecia not seen. Pycnidia not seen.

Chemistry. Major compound: sekikaic acid (or its positional isomer). Minor compounds: 4'-O-methylnorsekikaic acid, usnic acid, a compound which could be 4'-O-methylpaludosic acid or homosekikaic acid, or ramalinic B acid, and a last compound which could be 4'-O-demethylsekikaic acid or subpaludosic acid (Table 1). Spot tests: cortex P-, K-, KC-, C-, UV-; medulla P-, K+ pinkish-winey (sometimes hard to see), $\mathrm{C}+$ pink (sometimes hard to see), $\mathrm{KC}+$ pink (sometimes hard to see), $\mathrm{UV}+$ white.

Distribution and ecology. Coastal corticolous species only known from Europa Island, growing on Suriana maritima.

Notes. Among other species from the Scattered Islands, Ramalina dumeticola is morphologically the most similar species, but the macroscopical differences, including the shorter thallus size, which is twice as small, the darker thallus tinge, the brittle aspect of branches when dry, and the sparsely branched aspect allow rather robust segregation between both species that are recorded from distinct islands. Moreover, the UV medulla reaction, the absence of apothecia in Ramalina hivertiana, and the differences in population shapes, which form dense continuous colonies with the former species, and sparse ones of isolated individuals with Ramalina dumeticola contribute to justify segregation between the species.

Etymology. The species is dedicated to our friend and colleague, the French botanist Jean Hivert, who tirelessly dedicates his life to the study and conservation of the flora and natural habitats of the Scattered Islands. Up to now, he 


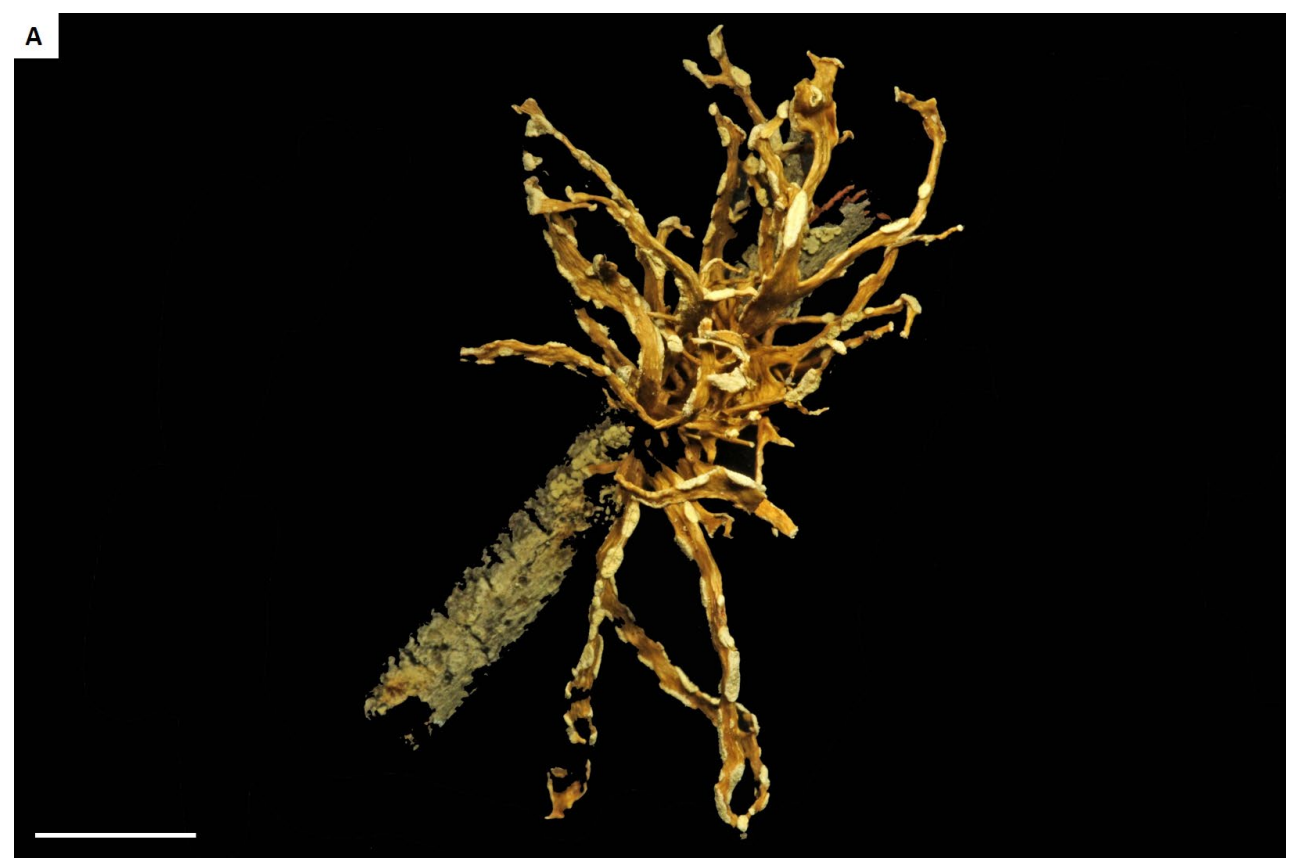

B

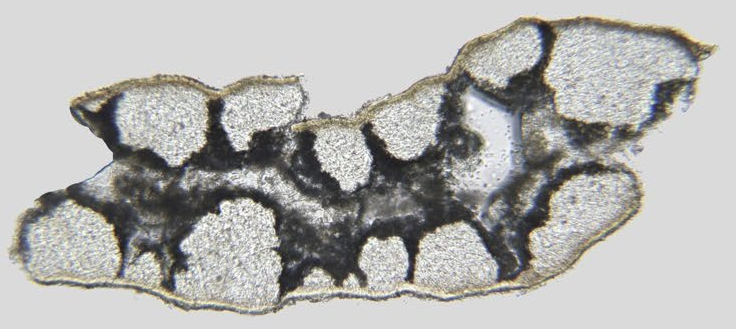

D

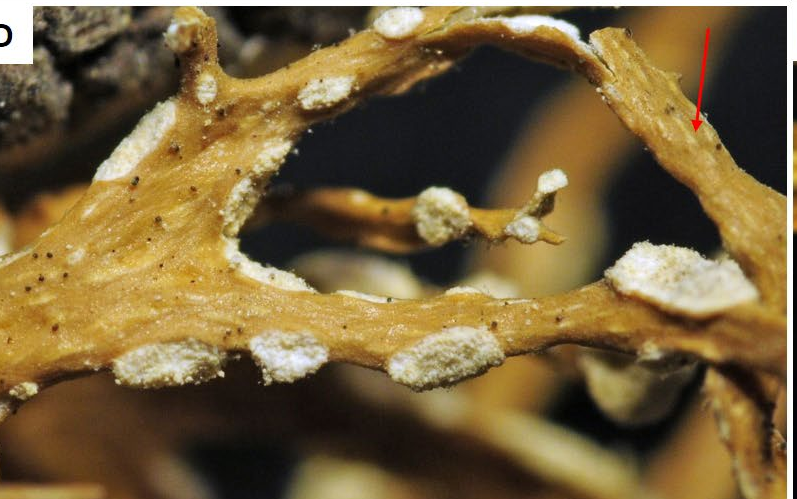

c
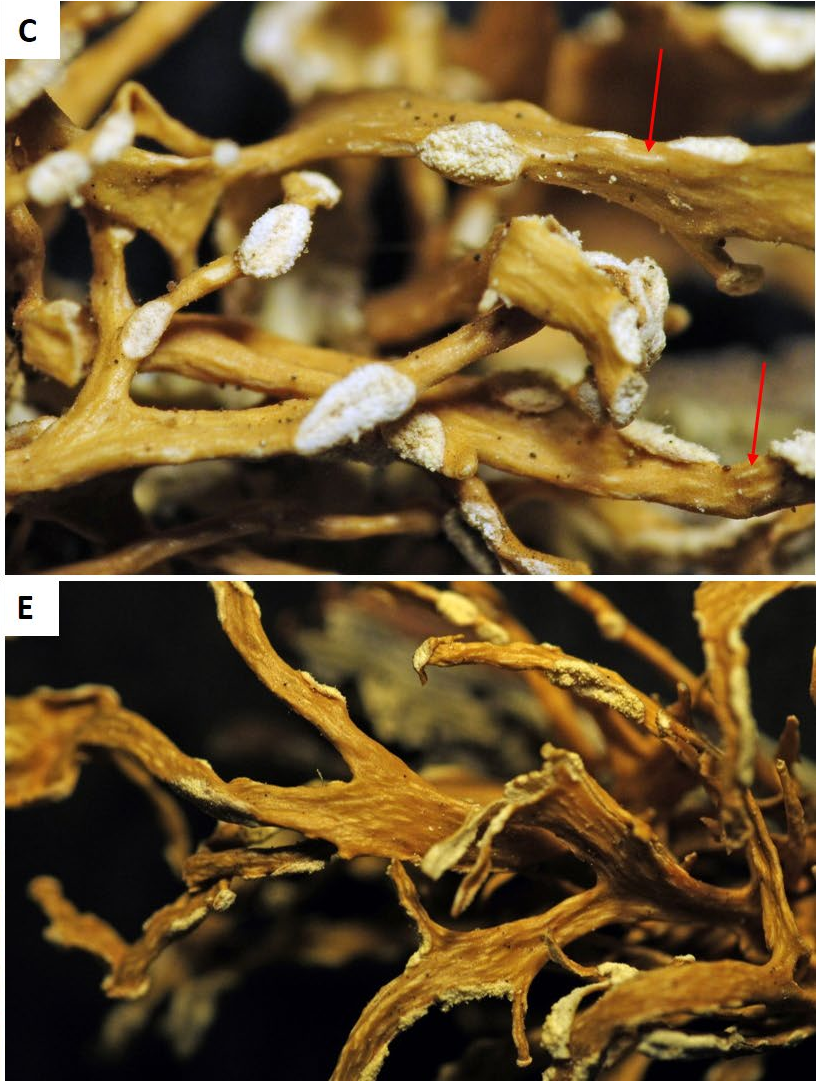

Figure 4. Ramalina hivertiana, holotype. A - habitus; B - internal structure of the laciniae; $\mathrm{C}-\mathrm{E}$ - close-up showing branches texture, marginal soralia and laminal pseudocyphellae. Scale $A=1 \mathrm{~cm} ; \mathrm{B}=0.25 \mathrm{~mm}$; $-\mathrm{E}=1 \mathrm{~mm}$.

has performed more than 470 days (32 missions) of field survey on these little uninhabited remote islands, greatly contributing to the recent increase of knowledge on their flora and habitats. J. Hivert was also the initiator and the coordinator of the RECOFFIE Project, within the frame of which all the recent material of Ramalina was collected.

Additional specimen. EUROPA ISLAND, 22²0'39.1581"S, $40^{\circ} 20^{\prime} 21.7748^{\prime \prime}$ E, 3 m a.s.1., corticolous on Suriana maritima, 11 April 2019, leg. R. Poncet 166, C. Fontaine, J. Hivert, E. Bidault (PC0739895 - isotype!).
Ramalina marteaui R. Poncet, sp. nov.

(Fig. 5)

MycoBank MB 841355

Diagnosis: Close to Ramalina maritima Krog \& Swinscow, but differing by not possessing a subpendulous thallus, the narrower branches (to 1-1.2 $\mathrm{mm}$ wide), the shorter ascospores and the absence of boninic acid (Krog \& Swinscow 1976; Swinscow \& Krog 1988).

Type: Glorioso Islands, $11^{\circ} 34^{\prime} 17.3558^{\prime \prime} \mathrm{S}, 47^{\circ} 17^{\prime} 53.6063^{\prime \prime} \mathrm{E}$, $3 \mathrm{~m}$ a.s.l., corticolous on dead branches of Suriana maritima, 21 April 2019, leg. R. Poncet 164, F. Picot, J. Hivert, E. Bidault (PC0739894 - holotype). 
Description. Thallus corticolous, dull, greenish-grey, fruticose, erected to 2-4(5) cm high, but often shorter, holdfast present, moderately branched, branching predominantly dichotomous. Branches solid, flattened, centrally canaliculated with often a distinct flattened area along margins, $0.5-1.2 \mathrm{~mm}$ wide, tapering apically, short, with inconspicuous marginal linear pseudocyphellae $(0.1-$ $0.3 \mathrm{~mm}$ length) forming barely visible ripples, and no laminal pseudocyphellae. Internal structure of the laciniae intermediate between continuous and cracked farinacea type, with distinguishable $10-15 \mu \mathrm{m}$ thick cortex, and noncracked chondroid tissue forming sub-separated (mostly on young branches) to separated strands adjoining the unbroken cortex. Soralia not seen. Apothecia lecanorine, 1.5-2.5 mm diam., lateral or marginal, on (sub-)geniculate branches, thalline exciple with a few linear pseudocyphellae (0.05-0.1 mm length), sometimes slightly crenulate, disc often showing cracks from surface view (generally on

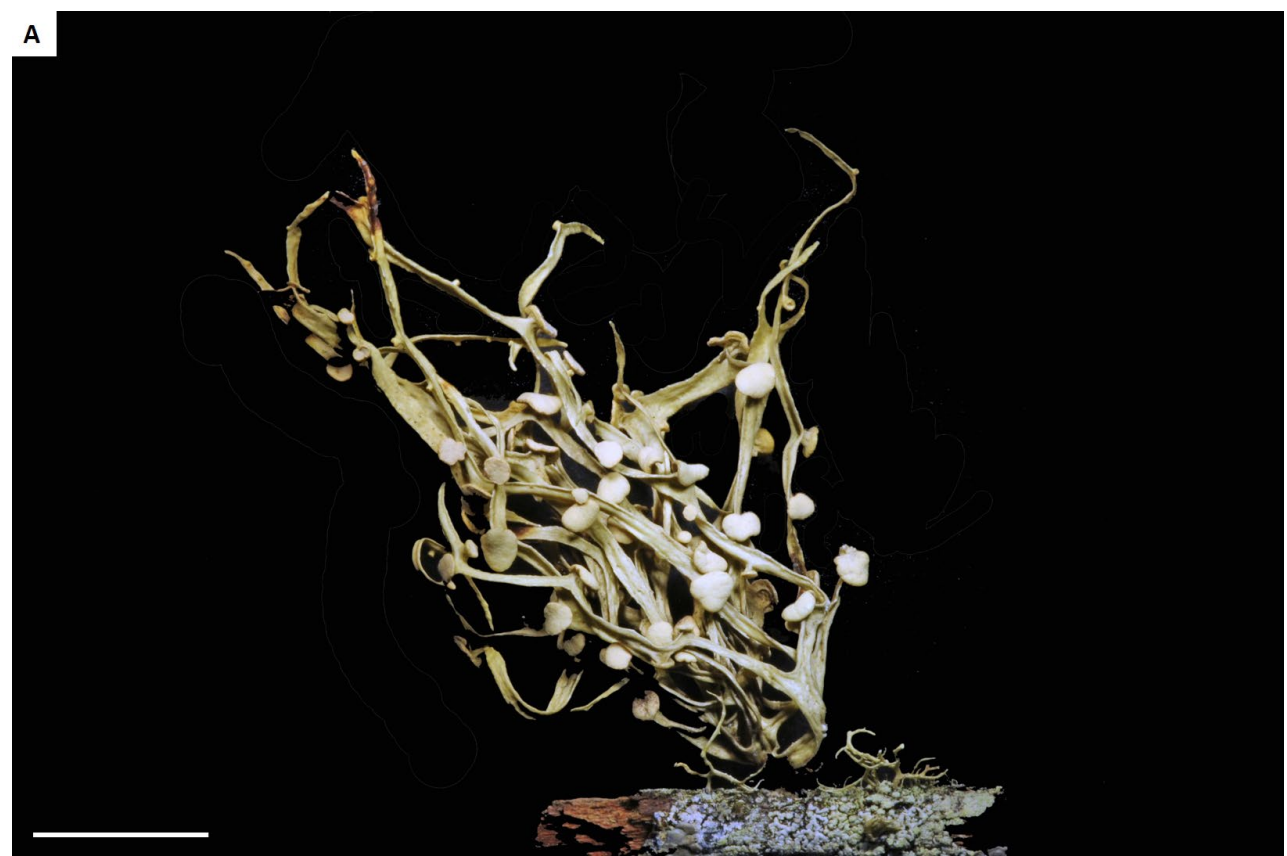

B

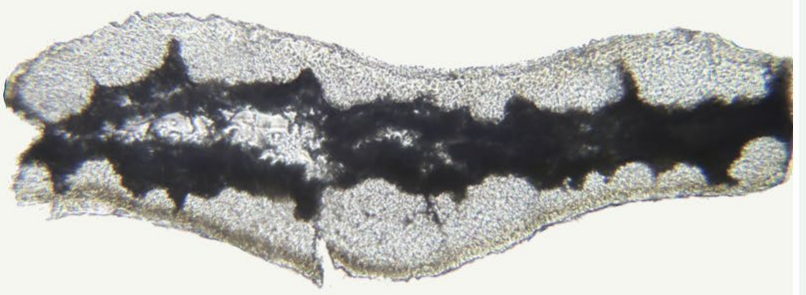

C
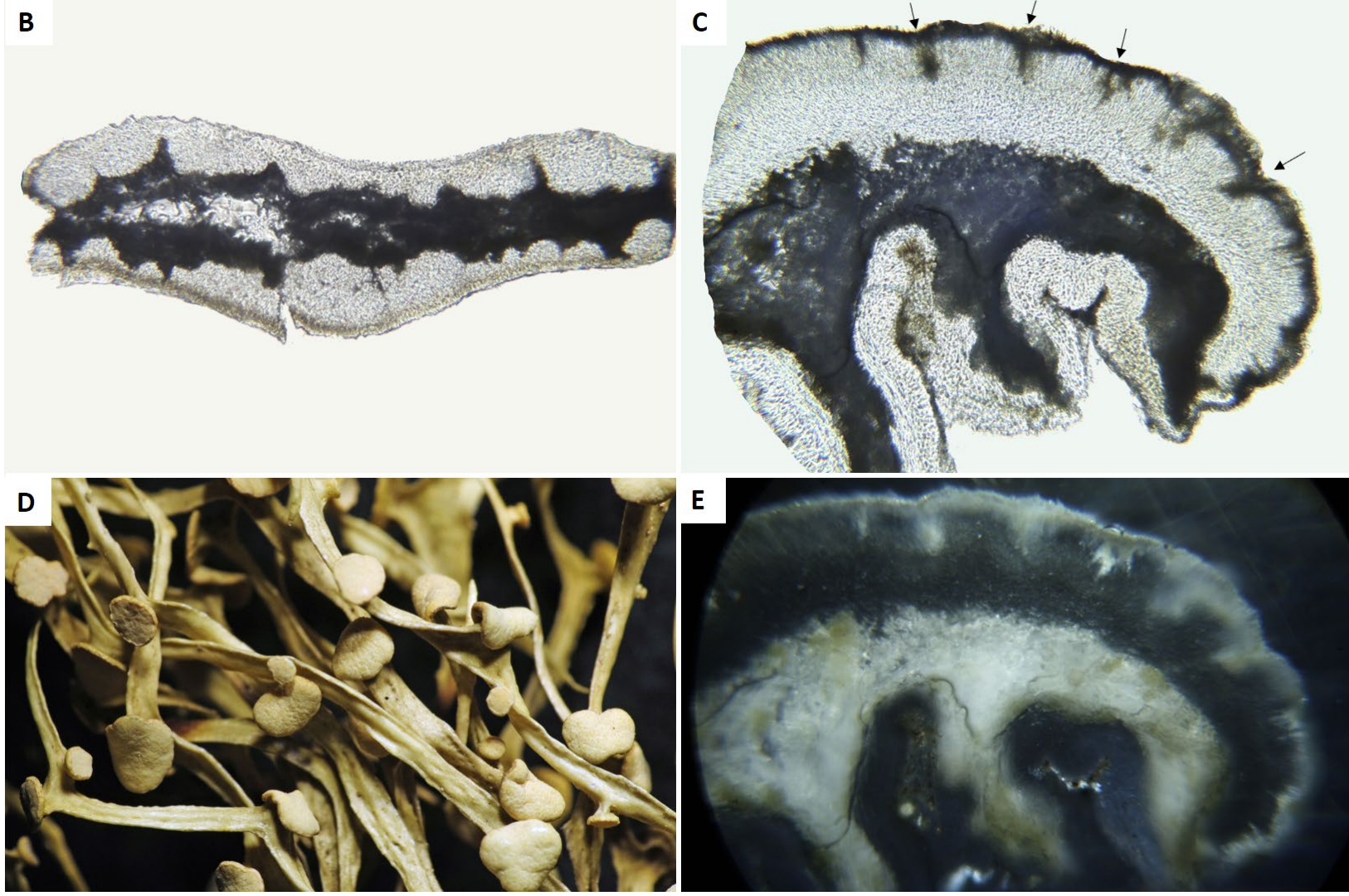

Figure 5. Ramalina marteaui, holotype. A - habitus; B - internal structure of the laciniae; C - apothecia cross-section in water (black arrows showing disc's cracks visible from surface view); D - close-up of branches and apothecia; E - apothecia cross-section in water under polarized light showing crystals locations. Scale A=1 cm; B-C=0.25 mm; D $=5 \mathrm{~mm} ; \mathrm{E}=0.25 \mathrm{~mm}$. 
mature to old apothecia). Hymenium hyaline, 50-70 $\mu \mathrm{m}$ high, paraphyses anastomosed, apically furcate, $1-1.5 \mu \mathrm{m}$ wide. Epithecium 7-10(12) $\mu \mathrm{m}$ high, brownish-olivaceous, with a layer of calcium oxalate crystals (1-4 $\mu \mathrm{m}$ diam.) visible in polarized light, dissolving in $\mathrm{K}$ (crystals forming vertical inclusions in hymenium at disc cracks location). Hypothecium hyaline, 30-40 $\mu \mathrm{m}$ high, with an algal layer below forming ovate clusters $(20-30 \times$ $40-50 \mu \mathrm{m})$ of rounded photobiont cells (4-7 $\mu \mathrm{m}$ diam.). Amphithecium generally undulating below the hymenium, of three layers, the external one consisting of 15-20 $\mu \mathrm{m}$ thick cortex, the second one of more or less abundant remains of chondroid tissue (up to 5-40 $\mu \mathrm{m}$ thick), and the last one of algal cells (4-8 $\mu \mathrm{m}$ diam.) intertwined with medulla and calcium oxalate crystals $(2-10 \mu \mathrm{m}$ diam.) visible in polarized light, partially dissolving in $\mathrm{K}$. Asci subclavate-cylindrical, 40-45 × 10-14 $\mu \mathrm{m}(\mathrm{n}=10)$, 8 -spored. Ascospores hyaline (surface seeming micro-verrucose), 12-16(18) × 4-5 $\mu \mathrm{m}(\mathrm{n}=30), 1$-septate (with sometimes 2 pseudosepta), fusiform, straight to curved. Pycnidia not seen.

Chemistry. Major compound: cryptochlorophaeic acid. Minor compound: usnic acid (Table 1). Spot tests: cortex P-, K-, KC-, C-, UV-; medulla P-, K+ red, C+ pink, KC+ pink, UV-; apothecial disc: $\mathrm{P}-, \mathrm{K}-, \mathrm{KC}-, \mathrm{C}-, \mathrm{UV}+$ dark reddish-brown.

Distribution and ecology. Coastal corticolous species only known from the type locality in the Glorioso Islands, growing on Suriana maritima.

Notes. The species is close to Ramalina maritima, but differ by not possessing a subpendulous thallus, the narrower branches (2-4 mm wide for $R$. maritima), the shorter ascospores $(18-25 \times 5-6 \mu \mathrm{m}$ for $R$. maritima) and the absence of boninic acid (Krog \& Swinscow 1976; Swinscow \& Krog 1988). It is also close to Ramalina holstii, and mostly differ by the inconspicuous marginal pseudocyphellae not raised on tubercles, forming barely visible ripples, and the bigger ascspores $(10-12 \times 2.5-3 \mu \mathrm{m}$ for $R$. holstii) and the absence of salazinic acid (Swinscow \& Krog 1988; Oh et al. 2014). It is also morphologically close to Ramalina fecunda, but differs by the shorter ascospores $(18-26 \times 4-5 \mu \mathrm{m}$ for $R$. fecunda), the absence of salazinic acid, the greenish-grey thallus (without yellow tinge), the absence of laminal pseudocyphellae and the non-splitting branch margin, (Krog \& Swinscow 1976; Swinscow \& Krog 1988). The new species also resembles Ramalina sp. A (Swinscow \& Krog 1988), but it has narrower branches (2-4 mm wide for $R$. sp. A) and smaller ascospores $(16-20 \times 5-6 \mu \mathrm{m}$ for $R$. sp. A).

Etymology. The species is dedicated to the French ornithologist and conservationist Cédric Marteau, who dedicates his life to actively improve conservation, knowledge, and visibility of the French Southern territories (Amsterdam Islands and Saint Paul, Crozet Islands, Kerguelen Islands) and the Scattered Islands.

Additional specimen. GLORIOSO ISLANDS, $11^{\circ} 34^{\prime} 17.3558^{\prime \prime} \mathrm{S}$, $47^{\circ} 17^{\prime} 53.6063^{\prime \prime} \mathrm{E}, 3 \mathrm{~m}$ a.s.1., corticolous on dead branches of
Suriana maritima, 21 April 2019, leg. R. Poncet 167, F. Picot, J. Hivert, E. Bidault (PC0739896).

\section{Ramalina ovalis Hook. f. \& Taylor}

Description. Thallus corticolous, dull, greenish-grey to pale stramineous (when dry), erected, 1.5-4(5) $\mathrm{cm}$ high and 1-4(5) cm wide, holdfast present, fan-shaped to palmate, or sparingly branched. Branches flattened, with rounded to blunt apices, solid and rigid, almost brittle when dry, with surface longitudinally ridged from strands of cartilaginous tissue (medulla sometimes almost inexistent), pseudocyphellae subpunctiform to shortly linear of $0.1-0.5 \mathrm{~mm}$ length. Internal structure of the laciniae cracked farinacea type, with distinguishable 10-15 $\mu \mathrm{m}$ thick cortex, and non-cracked chondroid tissue forming separated strands adjoining the broken cortex at pseudocyphellae locations and independent strands imbedded in the medulla. Soralia not seen. Apothecia lecanorine, mostly laminal, sometimes marginal, stipited, numerous, 1-2(3) mm diam, mainly concave, thalline excipulum entire, sometimes slightly crenate. Hymenium hyaline, 60-80 $\mu \mathrm{m}$ high, paraphyses anastomosed, apically furcate, $1-1.5 \mu \mathrm{m}$ wide. Epithecium $8-12 \mu \mathrm{m}$ high, pale brownish-olivaceous, with a layer of calcium oxalate crystals (1-4 $\mu \mathrm{m}$ diam.) visible in polarized light, dissolving in $\mathrm{K}$. Hypothecium hyaline, 30-40 $\mu \mathrm{m}$ high, with an algal layer below forming ovate clusters $(25-35 \times$ $40-50 \mu \mathrm{m})$ of rounded photobiont cells (5-8 $\mu \mathrm{m}$ diam.). Amphithecium of three layers, the external one consisting of 10-30 $\mu \mathrm{m}$ thick cortex (more or less visible), the second one of chondroid tissue (20-80 $\mu \mathrm{m}$ thick), and the last one of algal cells (5-10 $\mu \mathrm{m}$ diam.) intertwined with medulla and calcium oxalate crystals $(4-10 \mu \mathrm{m}$ diam.) visible in polarized light, partially dissolving in $\mathrm{K}$. Asci subclavate-cylindrical, 50-75 × 11-15 $\mu \mathrm{m}$ $(\mathrm{n}=10), 8$-spored. Ascospores hyaline (surface seeming micro-verrucose), (10-)12-16 × 4-5 $\mu \mathrm{m}(\mathrm{n}=30), 1$-septate, ellipsoid or slightly fusiform, straight to curved. Pycnidia not seen.

Chemistry. Major compound: usnic acid (Table 1). Spot tests: cortex P-, K-, KC+ yellow, C-, UV-; apothecial discs $\mathrm{P}-, \mathrm{K}+$ yellow turning pale wine (sometimes fleeting, best seen on young apothecia), $\mathrm{KC}+$ yellow-orange, $\mathrm{C}+$ yellow, UV-; medulla P-, K-, KC- yellow, UV-.

Distribution and ecology. Ramalina ovalis is known from Australia and New Zealand where it mostly grows under warm temperate climates with warm summers. Stevens (1987) also indicates that it is present among collections of $R$. celastri from high elevation locations in Tanzania (1,440 $\mathrm{m}$ a.s.1.) and Uganda (1,950-2,100 m a.s.1.). Only recorded from Europa Island in the present study, growing at sea level on Suriana maritima and Delonix regia.

Notes. The species is morphologically close to Ramalina, but differs by the broader and fewer branches, which are often fan-shaped to palmate, with rounded to blunt apices (Stevens 1987; Swinscow \& Krog 1988; 

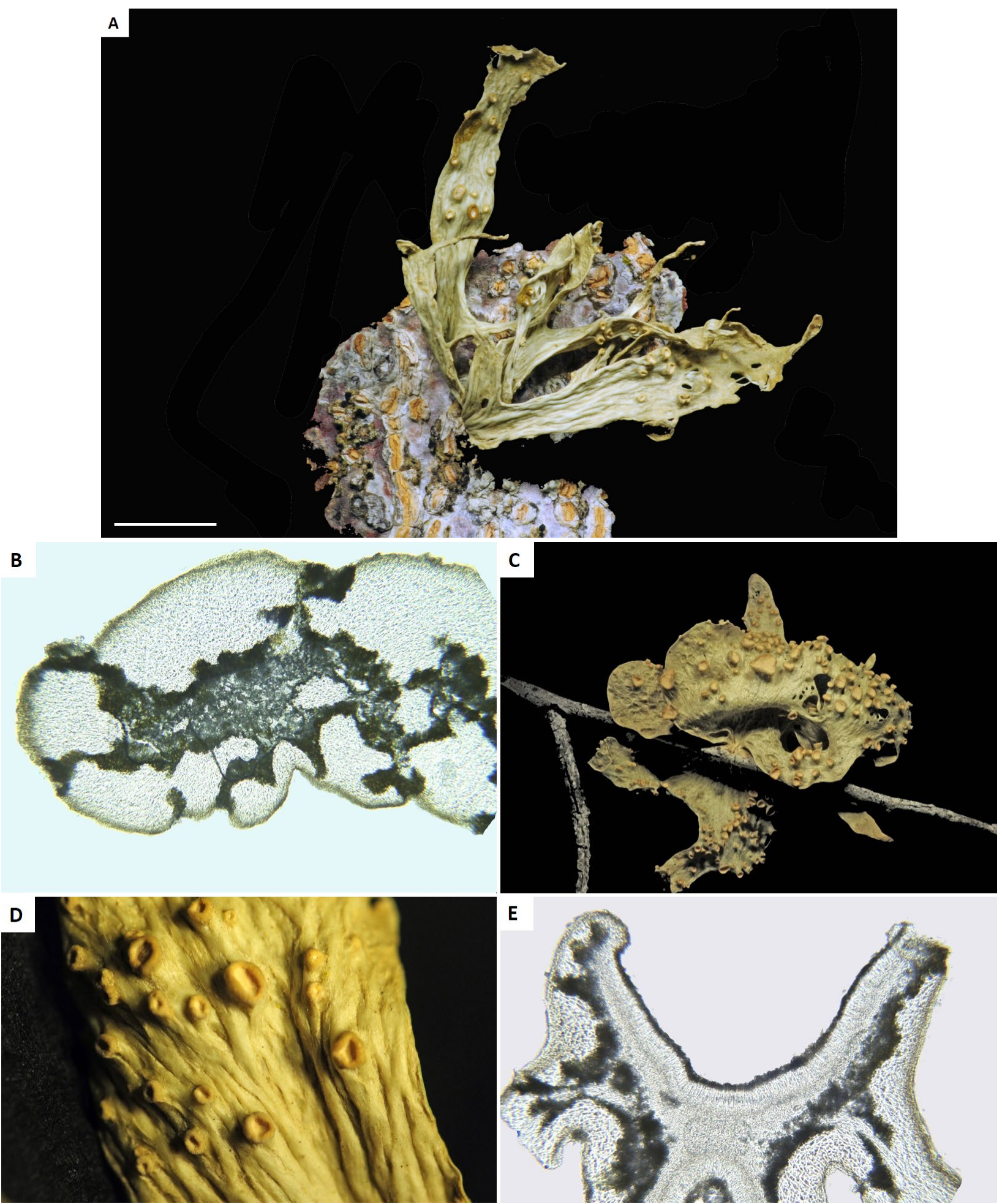

Figure 6. Ramalina ovalis, PC0739889, collected in 2019 in Europa Island. A - habitus; B - internal structure of the laciniae; C - habitus; D close-up of a branch showing apothecia and surface longitudinally ridged; $\mathrm{E}-$ apothecia cross-section in water. Scale $\mathrm{A}=1 \mathrm{~cm} ; \mathrm{B}=0.25 \mathrm{~mm}$; $\mathrm{C}=1 \mathrm{~cm} ; \mathrm{D}=2 \mathrm{~mm} ; \mathrm{E}=0.2 \mathrm{~mm}$.

Blanchon et al. 1996). It also resembles Ramalina leiodea, but $R$. ovalis differs by the wider branches, which are not canaliculated and not tapering distally, by the mostly laminal apothecia, and by the less abundant and shorter laminal pseudocyphellae (Stevens 1987). Ramalina sinensis Jatta is also morphologically similar, but differs by the non-dorsiventral thallus, and by the ecology and distribution (Kashiwadani et al. 2006; Oh et al. 2014).
Specimens examined. EUROPA ISLAND, 22²0'39.1581"S, $40^{\circ} 20^{\prime} 21.7748^{\prime \prime}$, 3 m a.s.1., corticolous on Suriana maritima, 11 April 2019, leg. R. Poncet 161, J. Hivert, C. Fontaine, E. Bidault (PC0739889); EUROPA ISLAND, 2220'39.3518"S, $40^{\circ} 20^{\prime} 21.9514 " \mathrm{E}, 3 \mathrm{~m}$ a.s.1., 11 April 2019, corticolous on Suriana maritima, leg. R. Poncet 162, J. Hivert, C. Fontaine, E. Bidault (PC0739888); EUROPA ISLAND, 22 20'42.8007"S, $40^{\circ} 20^{\prime} 25.6197 " \mathrm{E}, 3 \mathrm{~m}$ a.s.1., corticolous on Delonix regia, 10 April 2019, leg. R. Poncet 163, J. Hivert, C. Fontaine, E. Bidault (PC0739893). 


\section{Identification key to the Ramalina species of the Scattered Islands and morphologically similar species}

All species listed in this identification key are corticolous, have a solid thallus, shrubby or subpendulous at most, with branches flat to canaliculated (at most slightly subterete or terete apically, or when young). Identification of specimens from paleotropics remains a rather difficult task, and the use of additional keys like the ones provided by Swinscow \& Krog (1988) and Stevens (1987) will be of great help. Unfortunately, the lack of knowledge regarding species distribution in the Southern Hemisphere and morphological variability makes the use of chemical criteria still necessary for many species.

1 Soralia absent, apothecia common........... 2

Soralia present, apothecia rare ............9

2(1) Thallus unbranched to moderately branched, from fanshaped to palmate; branches strap-shaped, flattened to canaliculate, generally rather wide, from 0.5 to

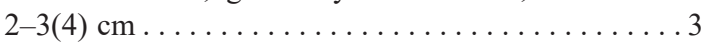

Thallus moderately branched; branches flattened to subterete or canaliculated, thin, from 0.5 to $2-3(4) \mathrm{mm}$ wide $\ldots \ldots \ldots \ldots \ldots \ldots \ldots \ldots \ldots \ldots$

3(2) Apothecia mostly on or close to the tips of the branches; branches often fan-shaped to more or less laciniate-fenestrate (particularly in older thallus), generally with a slightly dorsiventral aspect (lower surface paler than the upper one); circumboreal species. ..... R. sinensis Apothecia mostly on the branches surface and/or along margin; branches if fan-shaped no laciniate, or strapshaped, canaliculated or not; no dorsiventral aspect; pantropical to austral species . . . . . . . . . . 4

4(3) Apothecia mostly marginal (subterminal on small individuals), rarely laminal; branches flat, sometimes canaliculated when narrow, usually $(0.5-) 2-4(-10) \mathrm{mm}$ wide tapering distally; australasian species .... R. leiodea

Apothecia mostly laminal (and sometimes marginal); branches flat to canaliculate, fan-shaped to strapshaped........................ 5

5(4) Branches lanceolate, with apices mostly acute (sometimes blunt); pantropical species . . . . . . . . R . celastri Branches with variable shape, from fan-shaped to strapshaped, with apices rounded to blunt; paleotropical species . . . . . . . . . . . . ovalis

6(2) Pseudocyphellae punctiform, raised on conspicuous tubercles, mainly marginal; salazinic acid and usually also cryptochlorophaeic acid present $(\mathrm{P}+$ orange, $\mathrm{K}+$ red); East African species. . . . . . . . . R. holstii Pseudocyphellae linear, or irregular, not raised on conspicuous tubercles, or absent ............. 7

7(6) Thallus erect or subpendulous, usually more than $4 \mathrm{~cm}$ long; with boninic acid; East African species ........ ....................... maritima

Thallus tufted, erected, rarely more than $4 \mathrm{~cm}$ long; with salazinic acid, or cryptochlorophaeic acid, or an undetermined substance $\ldots \ldots \ldots \ldots \ldots \ldots \ldots$

8(7) Laminal pseudocyphellae absent (but marginal often present, inconspicuously raised); branches margin not split- ting, branches centrally canaliculated with often a distinct flattened area along margins; ascospores $12-16(18) \times$ 4-5 $\mu \mathrm{m}$; with cryptochlorophaeic acid; known from Glorioso Islands (Mozambique channel) . . R. marteaui

Laminal pseudocyphellae present; branches margin splitting or not, branches not canaliculated, on only weakly; ascospores comprised between 16-26 × 5-6 $\mu \mathrm{m}$; with salazinic acid or another undetermined substance; East African species . . . . . . . R. fecunda or R. sp. A. [see Swinscow \& Krog (1988)]

9(1) Soralia punctiform (sometimes ellipsoid), often producing small fibrils, marginal and apical; thallus delicate and fragile, densely branched; branches flat, compressed becoming angularly subterete or terete distally; with sekikaic acid aggregate; pantropical species . . . . . . . . ....................... peruviana

Soralia ellipsoidal or round, no producing fibrils, mostly marginal; thallus not delicate and lacking fragile branchlets; branches mostly flat. . . . . . . . . 10

10(9) Branches without pseudocyphellae; thallus extremely variable, usually with a greyish-greenish, or greyish-bluish, or bluish-greenish tinge (in West European material at least; contrary to what is frequently stated, we find that this species lacks a significant yellow tinge), generally sub-pendant to pendant; branches broad to narrow, 0.5-3(-4) mm wide, 3-7 cm long, usually flattened, but sometimes almost terete (mostly distally); soralia mostly marginal, but sometimes laminal also; with protocetraric acid, salazinic acid, hypoprotocetraric acid or norstictic acid, or no medullary metabolites; circumboreal species . . . . . . . . farinacea

Branches with pseudocyphellae (sometimes inconspicuous); thallus variable, but usually with at least a conspicuous yellowish tinge; tropical to austral species . . . . 11

11(10) Thallus dark stramineous to brownish ochraceous, short, to 2(3) $\mathrm{cm}$ long, moderately branched to unbranched; branches flattened, solid, rigid, brittle (or almost) when dry; pseudocyphellae conspicuous, laminal and marginal; without divaricatic acid, with sekikaic acid (or its positional isomer) as major compound, and 4'-O-methylnorsekikaic acid, usnic acid, and two other unidentified acids as minor compounds (belonging to paludosic, sekikaic or ramalinic acids aggregates); known from Europa Island (Mozambique Channel). . R. hivertiana Thallus paler, greenish-yellowish to greyish-stramineous, generally longer and more branched; branches not brittle when dry; with or without divaricatic acid; paleotropical-australasian species. . . . . . . . . . . 12

12(11) Medulla K-; thallus subpendulous to pendulous, 4-10 $\mathrm{cm}$ long (to $30 \mathrm{~cm}$ ); cortex marked with longitudinal pseudocyphellae; with divaricatic and stenosporic acids; paleotropical-australasian species ..... $R$. nervulosa Medulla $\mathrm{K}+$ pinkish-winey $\ldots \ldots \ldots \ldots \ldots \ldots 13$

13(12) Thallus subpendulous to pendulous, up to $7 \mathrm{~cm}$ long (exceptionally to $18 \mathrm{~cm}$ ); branches sparsely dichotomous, producing extreme elongation between dichotomies, slightly twisted along the whole length, the fusion between branches common; with sekikaic acid aggregate, and faint homosekikaic acid; australasian species....

R. luciae

Thallus subpendulous to erect, $3-6 \mathrm{~cm}$ long, without extreme elongation between dichotomies ........ 14 
14(13) Some branches splitting along the margins and apically; with salazinic acid as major compound and protocetraric acid as minor compound; australasian species .......

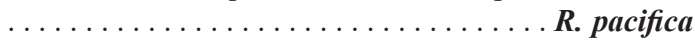

Branches non-splitting; absence of salazinic acid as major compound ...................... 15

15(14) Thallus with a conspicuous yellowish tinge; branches not intricated, branching angle narrow, often less than $70-80^{\circ}$; with sekikaic acid (or its positional isomer) and another compound which could be 4'-O-methylpaludosic acid or homosekikaic acid or ramalinic acid as major compound, with 4'-O-methylnorhomosekikaic acid as minor compound (in the material examined from Scattered islands); paleotropical-australasian species .....

R. dumeticola

Thallus conspicuously greyer (yellow tinge present, but far less intense), branches more or less intricated, wavy, sinuous, branching angle wider, often close to $80-90^{\circ}$; presence of sekikaic acid (or its positional isomer) as major compound, with 4'-O-methylnorsekikaic acid, and another compound that could be 4'-O-demethylsekikaic acid or subpaludosic acid as minor compound; known from Glorioso Islands (Mozambique Channel, Comoros area $\ldots \ldots \ldots \ldots \ldots \ldots \ldots \ldots$. gloriosensis

\section{Acknowledgments}

RP address special thanks to Sylvie Chevalier (UMS 2006 PatriNat), Mélanie Hubert (UMS 2006 PatriNat), Laurent Poncet (UMS 2006 PatriNat), Julien Touroult (UMS 2006 PatriNat), and Serge Muller (ISYEB - MNHN) for their trust and mostly for their invaluable help in this project and without whom none of this would have been possible. Sophie Marinesque (TAAF), Jonathan Grand (TAAF), and Cedric Marteau (TAAF), who coordinate the consortium and the field campaigns and invested countless energy and time for improving the Scattered Islands natural heritage knowledge and conservation, are also warmly thanked. FLD and SF thank Isabelle Rouaud for the help in the preparation of lichen extracts. EB is thankful to the Missouri Botanical Garden, and especially Porter P. Lowry II (head of the Africa and Madagascar Department) and Tariq Stévart (coordinator of West and Central Africa program) for financially supporting his activities in the Western Indian Ocean. We are grateful to the two anonymous reviewers who contributed to greatly improve the manuscript.

\section{Funding}

Species studied in this paper were collected in the frame of the 'Scattered Island' inter-agency research consortium (2017-2021) coordinated by the French Southern and Antarctic Lands (TAAF) in partnership with: Centre National de la Recherche Scientifique, Institut de Recherche pour le Développement, Ifremer, Office Français de la Biodiversité, Université de La Réunion \& Université de Mayotte. Fieldwork was funded by the inter-agency research consortium and was done jointly by the Conservatoire Botanique National de Mascarin, the Missouri Botanical Garden and the Muséum National d'Histoire Naturelle (UMS 2006 PatriNat OFB - CNRS - MNHN) in the frame of the RECOFFIE (Renforcement des COnnaissances sur la Flore et la Fonge des Iles Éparses) project, implemented as part of the 'Scattered Island' inter-agency research consortium (2017-2021). Species chemical profiling was funded by UMR 6226 (Université de Rennes, CNRS, Institut des Sciences Chimiques de Rennes).

\section{Permits}

Collecting of the lichen species were authorized in the Scattered Islands according to the permit delivered by C. Geoffroy, General Secretary of French Southern and Antarctic Lands and district head of the Scattered Island. The RECOFFIE (CBN-CPIE Mascarin, MBG, UMS 2006 PatriNat (OFB - CNRS - MNHN)) project was authorized by order n²019-40 of April 1, 2019.

\section{References}

Alvarez, J., Paz-Bermúdez, G. \& Sánchez-Biezma, M. J. 2001. Estudio quimiotaxonómico del género Ramalina Ach. (Lecanorales, Ascomycotina) en Galicia (NW de España). Cryptogamie, Mycologie 22(4): 271-287. https://doi.org/10.1016/s0181-1584(01)01075-2

Aptroot, A. 2008. Lichens of St Helena and Ascension Island. Botanical Journal of the Linnean Society 158: 147-171. https://doi. org/10.1111/j.1095-8339.2008.00797.x

Aptroot, A. 2016. Preliminary checklist of the lichens of Madagascar, with two new thelotremoid Graphidaceae and 131 new records. Willdenowia 46(3): 349-365. https://doi.org/10.3372/wi.46.46304

Aptroot, A. \& Bungartz, F. 2007. The lichen genus Ramalina on the Galapagos. The Lichenologist 39(6): 519-542. https://doi. org/10.1017/S0024282907006901

Aptroot, A. \& Schumm, F. 2008. Key to Ramalina species known from Atlantic islands, with two new species from the Azores. Sauteria 15: $21-57$.

Beck, H. E., Zimmerman, N. E., McVicar, T. R., Vergopolan, N., Berg, A. \& Wood, E. F. 2018. Present and future Köppen-Geiger climate classification maps at 1-km resolution. Scientific Data 5: 180-214. https://doi.org/10.1038/sdata.2018.214

Blanchon, D. J., Braggins, J. E. \& Stewart, A. 1996. The lichen genus Ramalina in New Zealand. Journal of the Hattori Botanical Laboratory 79: 43-98.

Bock, C., Hauck, M. \& Fischer, E. 2007. The lichen flora of Rwanda: an annotated checklist. Willdenowia 37: 563-575. https://doi. org/10.3372/wi.37.37216

Boullet, V., Hivert, J. \& Gigord, L. 2018. An updated account of the vascular flora of the Îles Eparses (Southwest Indian Ocean). Smithsonian Institution Scholarly Press, Washington.

Diedrich, P. \& Ertz, D. 2020. First checklist of lichens and lichenicolous fungi from Mauritius, with phylogenetic analyses and descriptions of new taxa. Plant and Fungal Systematics 65(1): 13-75. https:// doi.org/10.35535/pfsyst-2020-0003

Dodge, C. W. 1971. Some lichens of tropical Africa. V. Lecanoraceae to Physciacea. Beihefte zur Nova Hedwigia 38: 1-225.

Ferron, S., Berry, O., Olivier-Jimenez, D., Rouaud, I., Boustie, J., Lohezic-Le Dévéhat, F. \& Poncet, R. 2020. Chemical diversity of five coastal Roccella species from mainland France, the Scattered Islands, and São Tomé and Príncipe. Plant and Fungal Systematics 65(2): 247-260. https://doi.org/10.35535/pfsyst-2020-0021

Fryday, A. M. 2014. A new checklist of lichenized, lichenicolous and allied fungi reported from South Africa. Bothalia 45(1): 59-122. https://doi.org/10.4102/abc.v45i1.148

Kashiwadani, H. \& Kalb, K. 1993. The Genus Ramalina in Brazil. Lichenologist 25(1): 1-31. 
Kashiwadani, H., Moon, K. H. \& Lai, M.-J. 2006. The Genus Ramalina (Ascomycotina: Ramalinaceae) in Taiwan. Memoirs of the National Science Museum, Tokyo 44: 161-173.

Krog, H. 1990. New Ramalina species from Porto Santo, Madeira. Lichenologist 22(3): 241-247.

Krog, H. 1994. Typification and interpretation of Ramalina arabum. Acta Botanica Fennica 150: 99-104.

Krog, H. \& Østhagen, H. 1980. The genus Ramalina in the Canary Islands. Norwegian Journal of Botany 27: 255-296.

Krog, H. \& Swinscow, T. D. V. 1974. Ramalina species with a hollow thallus (Fistularia) in East Africa. Norwegian Journal of Botany 21: 111-124.

Krog, H. \& Swinscow, T. D. V. 1975. Some Ramalina species with punctiform pseudocyphellae in East Africa. Norwegian Journal of Botany 22: 269-276.

Krog, H. \& Swinscow, T. D. V. 1976. The genus Ramalina in East Africa. Norwegian Journal of Botany 23: 153-175.

Le Pogam, P., Pillot, A., Lohezic-Le Dévéhat, F., Le Lamer, A. C., Legouin, B., Gadea, A., Sauvager, A., Ertz, D. \& Boustie, J. 2017. Mass spectrometry as a versatile ancillary technique for the rapid in situ identification of lichen metabolites directly from TLC plates. The Lichenologist 49(5): 507-520. https://doi.org/10.1017/ S0024282917000433

Lücking, R., Hodkinson, B. P. \& Leavitt, S. D. 2016. The 2016 classification of lichenized fungi in the Ascomycota and Basidiomycota Approaching one thousand genera. The Bryologist 119(4): 361-416.

Neuwirth, G. \& Stocker-Wörgötter, E. 2017. Twenty-five lichen species new to Seychelles. Stapfia 107: 153-161.
Oh, S. O., Wang, X. Y., Wang, L. S., Liu, P. G. \& Hur, J. S. 2014 A note on the lichen genus Ramalina (Ramalinaceae, Ascomycota) in the Hengduan Mountains in China. Mycobiology 42(3): 229-240. https://doi.org/10.5941/MYCO.2014.42.3.229

Pérez-Vargas, I. \& Pérez-Ortega, S. 2014. A new endemic Ramalina species from the Canary Islands (Ascomycota, Lecanorales). Phytotaxa 159(4): 269-278. https://doi.org/10.11646/phytotaxa.159.4.3

Seaward, M. R. D. \& Aptroot, A. 2009. Checklist of lichens for the Seychelles group. Bibliotheca Lichenologica 99: 335-366.

Sparrius, L. B., Aptroot, A., Sipman, H. J. M., Pérez-Vargas, I., Matos, P., Gerlach, A. \& Vervoort, M. 2017. Estimating the population size of the endemic lichens Anzia centrifuga (Parmeliaceae) and Ramalina species (Ramalinaceae) on Porto Santo (Madeira archipelago). The Bryologist 120(3): 293-301. https://doi.org/10.1639/0007-2745120.3.293

Stevens, G. N. 1983. Tropical-Subtropical Ramalinae in the Ramalina farinacea complex. The Lichenologist 15(3): 213-229.

Stevens, G. N. 1987. The lichen genus Ramalina in Australia. Bulletin of the British Museum (Natural History), Botany Series 16(2): $107-223$.

Swinscow, T. D. V. \& Krog, H. 1988. Macrolichens of East Africa. British Museum (Natural History), London.

Yoshimura, I., Kinoshita, Y., Yamamoto, Y., Huneck, S. \& Yamada, Y. 1994. Analysis of Secondary Metabolites from Lichen by High Performance Liquid Chromatography with a Photodiode Array Detector. Phytochemical Analysis 5: 197-205. 